\title{
Quantitative receptor radioautography in the study of receptor-receptor interactions in the nucleus tractus solitarii
}

\section{D.R. Fior-Chadi ${ }^{1}$} and K. Fuxe ${ }^{2}$

\author{
'Departamento de Fisiologia, Instituto de Biociências, Universidade de São Paulo, \\ São Paulo, SP, Brasil \\ ${ }^{2}$ Department of Neuroscience, Karolinska Institute, Stockholm, Sweden
}

\section{Correspondence \\ D.R. Fior-Chadi \\ Departamento de Fisiologia Instituto de Biociências, USP \\ Rua do Matão, Travessa 14, 321 05508-900 São Paulo, SP Brasil \\ Fax: 55 (011) 818-7416 \\ E-mail:drfchadi@usp.br}

Presented at the 5th International Symposium on Radioautography, São Paulo, SP, Brasil,

August 24-26, 1997.

Research supported by FAPESP, CNPq and the Swedish Medical Research Council (No. 04X-715).

Received September 23, 1997 Accepted November 14, 1997

\section{Abstract}

The nucleus tractus solitarii (NTS) in the dorsomedial medulla comprises a wide range of neuropeptides and biogenic amines. Several of them are related to mechanisms of central blood pressure control. Angiotensin II (Ang II), neuropeptide Y (NPY) and noradrenaline (NA) are found in the NTS cells, as well as their receptors. Based on this observation we have evaluated the modulatory effect of these peptide receptors on $\alpha_{2}$-adrenoceptors in the NTS. Using quantitative receptor radioautography, we observed that NPY and Ang II receptors decreased the affinity of $\alpha_{2}$-adrenoceptors for their agonists in the NTS of the rat. Cardiovascular experiments agreed with the in vitro data. Coinjection of a threshold dose of Ang II or of the NPY agonists together with an $\mathrm{ED}_{50}$ dose of adrenergic agonists such as NA, adrenaline and clonidine counteracted the depressor effect produced by the $\alpha_{2}$-agonist in the NTS. The results provide evidence for the existence of an antagonistic interaction between Ang II AT1 receptors and NPY receptor subtypes with the $\alpha_{2}$-adrenoceptors in the NTS. This receptor interaction may reduce the transduction over the $\alpha_{2}$ adrenoceptors which can be important in central cardiovascular regulation and in the development of hypertension.

The nucleus tractus solitarii (NTS) in the medulla oblongata has a crucial role in central cardiovascular control. This nucleus receives primary afferents which derive from visceral receptors such as cardiopulmonary, gut, hepatic and pancreatic receptors, chemoreceptors, and baroreceptors via the vagus and glossopharyngeal nerves $(1,2)$. Several lines of evidence suggest that the NTS, particularly its medial portion, is absolutely essential to baroreceptor reflex integrity $(1,3)$. Lesions or pharmacological blockade of the NTS effectively eliminate the

\section{Key words}

- Quantitative radioautography

- Nucleus tractus solitarii

- Alpha-2-adrenoceptors

- Neuropeptide Y receptors

- Angiotensin II receptors baroreceptor reflex responses (3). Electrical or pharmacological activation of the medial NTS mimics baroreceptor reflex responses, i.e., causes a reduction in mean arterial blood pressure, heart rate and sympathetic nerve activity similar to that induced by electrical stimulation of the aortic depressor nerve, the carotid sinus nerve or the nerve trunk containing baroreceptor afferents $(1,3)$. Furthermore, the NTS is a converging area for the information from other cardiovascular centers. Electrophysiological techniques have confirmed that afferent fibers from other 
brainstem and higher brain nuclei may exert a modulatory role in the activity of the NTS neurons induced by activation of peripheral cardiovascular afferent fibers. The NTS neurons activated by stimulation of baroreceptor and visceral afferent nerves can also respond to electrical stimulation of the cerebellum (4), the parabrachial nucleus (5), the hypothalamus (2), the ventrolateral medulla (6) and the central nucleus of the amygdaloid complex (7). Thus, the NTS acts as an important cardiovascular center by integrating the cardiovascular information from peripheral receptors and other cardiovascular centers.

Another outstanding feature of the NTS is the large quantity and diversity of neurotransmitters/neuromodulators and their receptors localized in this nucleus $(1,8)$. Nonpeptidergic systems such as biogenic amines $(9,10)$, histamine (11) and acetylcholine are present (12), as well as most of the known mammalian peptidergic systems including thyrotropin-releasing hormone (13), corticotropin-releasing factor (14), vasopressin (15), oxytocin (16), adrenocorticotropic hormone (17), B-endorphin (18), dynorphin (19), enkephalins (20), substance P (21), vasoactive intestinal polypeptide (22), bombesin (23), galanin (24), neurotensin (25), calcitonin gene-related peptide (26), angiotensin II (27), and neuropeptide Y (28).

Among these neurotransmitters, the catecholamines, neuropeptide Y (NPY) and an-

Table 1 - Summary of the results obtained by the modulation of the $\alpha_{2}$ adrenoceptors by NPY and Ang II receptors.

The binding parameters were obtained from saturation curves of $\left[{ }^{3} \mathrm{H}\right]-\mathrm{PAC}$ in the NTS using quantitative receptor radioautography. Cardiovascular parameters were obtained by injection of $\alpha_{2}$-adrenoceptor agonists into the NTS and simultaneous recording of blood pressure in anesthetized animals.

\begin{tabular}{|c|c|c|c|c|}
\hline & \multicolumn{2}{|c|}{ Binding parameters } & \multicolumn{2}{|c|}{ Cardiovascular parameters } \\
\hline & $K_{D}$ & $\mathrm{~B}_{\max }$ & Hypotension & Bradycardia \\
\hline NPY & $\uparrow$ & unchanged & counteracted & counteracted \\
\hline Ang II & $\uparrow$ & $\uparrow$ & counteracted & unchanged \\
\hline
\end{tabular}

giotensin II (Ang II) are of special interest concerning central cardiovascular control (29-31). Evidence suggests a central inhibitory role of catecholamines in the regulation of blood pressure and heart rate since decreases in blood pressure and heart rate were observed following intraventricular injection of noradrenaline into the NTS (32). NPY in the NTS possesses cardiovascular effects similar to those observed for catecholamines, leading to a prolonged decrease in arterial pressure and heart rate $(33,34)$. Ang II is also well characterized as a participant in the mechanisms of blood pressure control (29,31). Ang II injected into the brain ventricular system leads to an increase in blood pressure. In the NTS Ang II seems to have a more variable effect, i.e., a depressor action at low doses followed by a pressor response (31). It is also suggested that Ang II inhibits the baroreceptor reflex (35).

These neurotransmitters share another interesting feature. NPY and Ang II coexist in catecholaminergic cell bodies and nerve terminals $(36,37)$. Furthermore, an overlap of the $\alpha_{2}$-adrenoceptor $(38,39)$, NPY receptor $(40)$ and Ang II receptor $(41,42)$ distribution is observed in the NTS (Figure 1).

These morphological substrates suggest that these neurotransmission lines may interact with one another in the NTS. In support of this view, it has been shown that NPY and adrenaline injected intraventricularly in the awake rat can antagonize the hypotensive actions of one another (43). It has also been shown that NPY reduces the affinity of $\left[{ }^{3} \mathrm{H}\right]-$ p-aminoclonidine $\left(\left[{ }^{3} \mathrm{H}\right]\right.$-PAC) binding sites in membrane preparations from the rat dorsomedial medulla (30).

These findings and the existence of interaction among other neurotransmission lines in different brain areas such as between substance $\mathrm{P}$ and 5-HT receptors (44), cholecystokinin and dopamine D2 receptors (45), neurotensin and dopamine D2 receptors (46) led us to evaluate carefully the possible existence of an interaction among the neu- 
rotransmission lines involved in cardiovascular control in the NTS.

The experiments were designed to evaluate in vitro the alterations in binding parameters of one specific receptor in the presence of another receptor system being activated at the same time. Furthermore, in vivo experiments were performed in order to obtain insights about the physiological meaning of those interactions.

Table 1 summarizes the results of the analysis of the modulation of the $\alpha_{2}$-adrenoceptors by peptide receptors such as NPY and Ang II.

The in vitro modulation of the $\alpha_{2}$-adrenoceptors was evaluated by analyzing the binding parameters of $\left[{ }^{3} \mathrm{H}\right]-\mathrm{PAC}$, an $\alpha_{2}-$ adrenoceptor agonist, in the presence or absence of different concentrations of NPY (40) and of Ang II (38). We employed quantitative radioautography which provides a good anatomical resolution for studying the NTS and is also a sensitive method for determining binding parameters.

The $K_{D}$ (dissociation constant) value of $\left[{ }^{3} \mathrm{H}\right]-\mathrm{PAC}$ was increased in the presence of NPY and Ang II. This means that the affinity of the $\alpha_{2}$-adrenoceptor for $\left[{ }^{3} \mathrm{H}\right]-P A C$ was reduced in the presence of NPY and Ang II.

Noradrenaline and other $\alpha_{2}$-adrenoceptor agonists such as adrenaline and clonidine $(47,48)$ induce a decrease in blood pressure when injected into the NTS. The modulation of $\alpha_{2}$-adrenoceptors in vivo was evaluated by injecting into the NTS an $\mathrm{ED}_{50}$ dose of an $\alpha_{2}$-adrenoceptor agonist such as noradrenaline in the presence or absence of a threshold dose of NPY or Ang II. A threshold dose was chosen as a dose that had no effect on blood pressure or heart rate. We observed that NPY (40) and Ang II (38) counteracted the decrease in blood pressure triggered by the injection of noradrenaline into the NTS.

The in vivo findings are in line with the data obtained with quantitative radioautography. In vitro, NPY and Ang II decreased the affinity of the $\alpha_{2}$-adrenoceptor for its agonist which could lead to a reduced transduction over the activated $\alpha_{2}$-adrenoceptor in the NTS.

These modulatory effects of peptides on the $\alpha_{2}$-adrenoceptor seem to be specific for areas rich in Ang II receptors and $\alpha_{2}$-adrenoceptors like the NTS. No modulatory effect by Ang II was observed on the $\alpha_{2}$-adrenoceptor in the amygdala (38), an area exhibiting a high density of $\alpha_{2}$-adrenoceptors (49) but very low levels of Ang II receptors (50).

In support of these findings, an antagonistic interaction between Ang II AT1 receptors and $\alpha_{2}$-adrenoceptors in the ventrolateral medulla has been described since angiotensin III was able to counteract the vasodepressor and bradycardic effects of guanabenz (51).

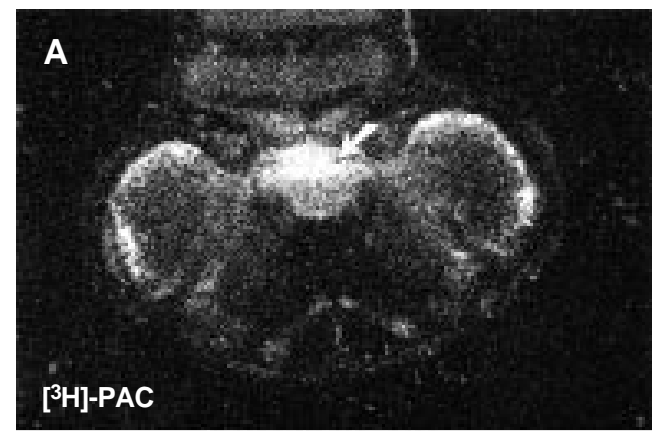

Figure 1 - Autoradiograms of coronal sections of the medulla oblongata of the rat showing the binding of different ligands in the nucleus tractus solitarii (arrow). $A$, Binding of $\left[{ }^{3} \mathrm{H}\right]-\mathrm{p}$ aminoclonidine $\left(\left[{ }^{3} \mathrm{H}\right]-\mathrm{PAC}\right) . \quad B$ Binding of $\left[{ }^{125} \mathrm{I}\right]$-angiotensin II ([ $\left.{ }^{125} \mathrm{l}\right]$-Ang II). C, Binding of [ [ $\left.{ }^{125} \mathrm{l}\right]$ neuropeptide $Y\left(\left[{ }^{125} \mathrm{I}\right]-\mathrm{PYY}\right)$.
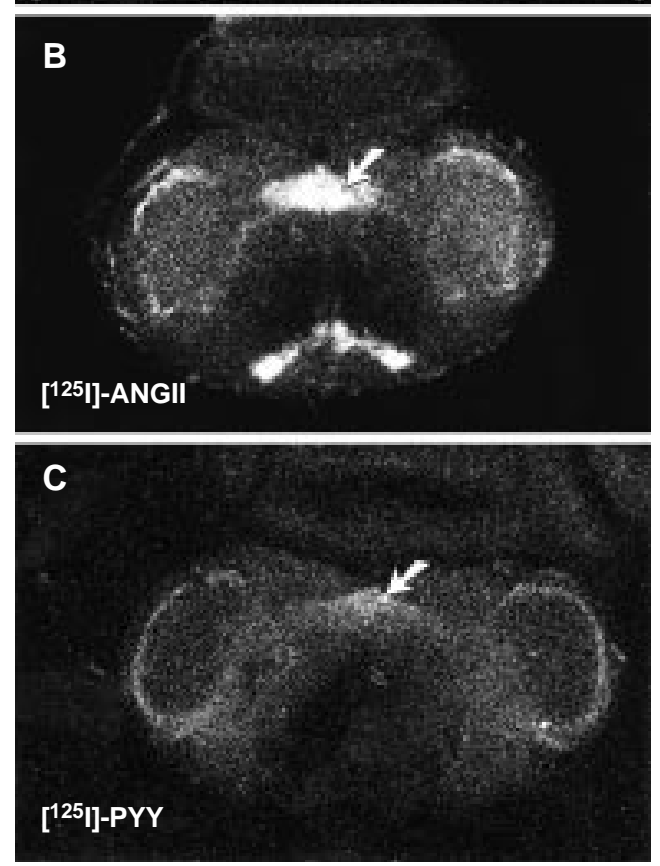
Furthermore, interactions between the NPY receptor and the $\alpha_{2}$-adrenoceptor have been described in other systems. Illes and Regenold (52) showed that NPY increased the hyperpolarizing effect of $\alpha_{2}$-agonists such as noradrenaline and UK 14304 on locus ceruleus cells but had no effect on (Met ${ }_{5}$ )enkephalin or (D-Ala 2 , D-Leu ${ }_{5}$ )-enkephalin at opioid $\mu$-receptors. These findings are in agreement with ours and suggest that NPY inhibits the action of catecholamines via a receptor-receptor interaction. Tsuda and collaborators (53) also suggested an interaction between NPY $/ \alpha_{2}$ adrenergic receptors since NPY inhibited the stimulation-evoked $\left[{ }^{3} \mathrm{H}\right]-$ norepinephrine release in slices of the medulla oblongata.

These findings suggest the existence of receptor-receptor interactions involving the $\alpha_{2}$-adrenoceptor and the NPY and Ang II receptors. These neurotransmission systems are involved in the mechanisms of blood pressure control and these interactions may have a role in the integration of extracellular signals in the central control of blood pressure. Actually, the receptor-receptor interactions among these neurotransmitter systems are altered in the NTS of spontaneously hypertensive rats $(54,55)$, highlighting the possible participation of these interactions in the central mechanisms controlling blood pressure.

Although the presence of receptor-receptor interaction has been identified in several systems, the exact mechanism of this phenomenon has not yet been elucidated. A probable mechanism involves the participation of the $G$ protein. The reduction of affinity of the $\alpha_{2}$-adrenoceptors induced by NPY in membranes of the medulla oblongata was blocked by pretreatment with pertussis toxin (56). The treatment with pertussis toxin was also able to counteract the cardiovascular actions of both NPY and clonidine administered to the intraventricular system of the rat (57). The $G$ protein seems to be also important in the modulation of $\alpha_{2}-$ adrenoceptors by bradykinin in the NTS (58).

\section{References}

1. Andresen MC \& Kunze DL (1994). Nucleus tractus solitarius-gateway to neural circulatory control. Annual Review of Physiology, 56: 93-116.

2. Mifflin SW, Spyer KM \& Withington-Wray DJ (1988). Baroreceptor inputs to the nucleus tractus solitarius in the cat: modulation by the hypothalamus. Journal of Physiology, 399: 369-387.

3. Reis DJ (1984). The brain and hypertension: reflections on 35 years of inquiry into the neurobiology of the circulation. Circulation, 70 (Suppl): 31-45.

4. Paton JF, Silva-Carvalho L, Goldsmith GE \& Spyer KM (1990). Inhibition of barosensitive neurones evoked by lobule Ixb of the posterior cerebellar cortex in the decerebrate rabbit. Journal of Physiology, 427: 553-565.

5. Felder RB \& Mifflin SW (1988). Modulation of carotid sinus afferent input to nucleus tractus solitarius by parabrachial nucleus stimulation. Circulation Research, 63: 35-49.
6. Paton JF, Rogers WT \& Schwaber JS (1991). The ventrolateral medulla as a source of synaptic drive to rhythmically firing neurons in the cardiovascular nucleus tractus solitarius of the rat. Brain Research, 561:217-229.

7. Cox GE, Jordan D, Moruzzi P, Schwaber JS, Spyer KM \& Turner AS (1986). Amygdaloid influences on brain-stem neurones in the rabbit. Journal of Physiology, 381: 135-148.

8. van Giersbergen PLM, Palkovits M \& De Jong W (1992). Involvement of neurotransmitters in the nucleus tractus solitarii in cardiovascular regulation. Physiological Reviews, 72: 789-824.

9. Armstrong DM, Ross CA, Pickel VM, Joh TH \& Reis DJ (1982). Distribution of dopamine-, noradrenaline-, and adrenaline-containing cell bodies in the rat medulla oblongata demonstrated by the immunocytochemical localization of catecholamine biosynthetic enzymes. Journal of Comparative Neurology, 212: 173-187.
10. Hökfelt T, Fuxe $\mathrm{K}$, Goldstein $M$ \& Johansson O (1973). Evidence for adrenaline neurons in the rat brain. Acta Physiologica Scandinavica, 89: 286-288.

11. Watanabe T, Taniguchi $Y$, Shiosaka $S$, Tanaka J, Kubota H, Terano Y, Tohyama M \& Wada H (1984). Distribution of the histaminergic neuron system in the central nervous system of rats: a fluorescent immunohistochemical analysis with histidine decarboxylase as a marker. Brain Research, 295: 13-25.

12. Armstrong DM, Rotler A, Hersh LB \& Pickel VM (1988). Localization of choline acetyltransferase in perikarya and dendrites within the nuclei of the solitary tract. Journal of Neuroscience Research, 20: 279-290.

13. Hökfelt T, Fuxe K, Johansson O, Jeffcoate S \& White N (1975). Thyrotropin releasing hormone $(\mathrm{TRH})$-containing nerve terminals in certain brain stem nuclei and in the spinal cord. Neuroscience Letters, 1: 133139. 
14. Gray TS \& Magnuson DJ (1987). Neuropeptide neuronal efferents from the bed nucleus of the stria terminalis and central amygdaloid nucleus to the dorsal vagal complex in the rat. Journal of Comparative Neurology, 262: 365-374.

15. Brinton RE, Gee KW, Wamsley LK, Davis TP \& Yamamura HL (1984). Regional distribution of putative vasopressin receptors in rat brain and pituitary by quantitative autoradiography. Proceedings of the National Academy of Sciences, USA, 81: 7248-7252.

16. Buijs RM (1978). Intra- and extrahypothalamic vasopressin and oxytocin pathways in the rat. Pathways to the limbic system, medulla oblongata and spinal cord. Cell and Tissue Research, 192: 423-435.

17. Joseph AS, Pilcher WH \& Bennet CC (1983). Immunocytochemical localization of ACTH perikarya in the nucleus tractus solitarius: evidence for a second opiocortin neuronal system. Neuroscience Letters, 38: 221-225.

18. Palkovits M, Mezey E \& Eskay RL (1987). Pro-opiomelacortin-derived peptides (ACTH/ $\beta$-endorphin $/ \alpha-M S H)$ in brainstem baroreceptor areas of the rat. Brain Research, 436: 323-338.

19. Fodor M, Csiffary A, Kiss $P$ \& Palkovits $M$ (1990). Dynorphin A-containing neural elements in the nucleus of the solitary tract of the rat. Light and electron microscopic immunohistochemistry. Brain Research, 522: 251-258.

20. Kalia M, Fuxe K, Hökfelt T, Johansson O, Lang R, Ganten D, Cuello C \& Terenius L (1984). Distribution of neuropeptide immunoreactive nerve terminals within the subnuclei of the nucleus of the tractus solitarius of the rat. Journal of Comparative Neurology, 222: 409-444.

21. Yamazoe M, Shiosaka S, Shibasaki T, Ling N, Tateishi K, Hashimura E, Hamaoka T, Kimmel JR, Matsuo H \& Toyama M (1984). Distribution of six neuropeptides in the nucleus tractus solitarii of the rat: an immunohistochemical analysis. Neuroscience, 13: 1243-1266.

22. Palkovits $M$, Leranth $C$, Eiden LE, Rotsztejn W \& Williams TH (1982). Intrinsic vasoactive intestinal polypeptide (VIP)containing neurons in the baroreceptor portion of the nucleus of the solitary tract in the rat. Brain Research, 244: 351-355.

23. Riche $D$, De Pommery $J$ \& Menetrey $D$ (1990). Neuropeptide and catecholamines in efferent projections of the nuclei of the solitary tract in the rat. Journal of Comparative Neurology, 293: 399-424.
24. Melander T, Hökfelt $\mathrm{T}$, Rokaeus $\mathrm{A}$, Cuello AC, Oertel WH, Verhofstad A \& Goldstein M (1986). Coexistence of galanin-like immunoreactivity with catecholamines, 5hydroxytryptamine, GABA and neuropeptides in the rat CNS. Journal of Neuroscience, $6: 3640-3654$.

25. Higgins GA, Hoffman GE, Wray $S$ \& Schwaber JS (1984). Distribution of neurotensin-immunoreactivity within baroreceptive portions of the nucleus of the tractus solitarius and the dorsal vagal nucleus of the rat. Journal of Comparative Neurology, 226: 155-164.

26. Morishima $\mathrm{Y}$, Takagi $\mathrm{H}$, Akai $\mathrm{F}$, Tohyama M, Emson PC, Hillyard CJ, Girgis SI \& MacIntyre I (1985). Light and electron microscopic studies of calcitonin gene-related peptide-like immunoreactive neurons and axon terminals of the nucleus of the tractus solitarius of the rat. Brain Research, 344: 191-195.

27. Healy DP, Rettig R \& Printz MP (1984). Evidence of an endogenous Ang II system in the rat nucleus tractus solitarius. Clinical and Experimental Hypertension, A6: 1743-1747.

28. Chronwall BM, DiMaggio DA, Massari VJ, Pickel VM, Ruggiero DA \& O'Donohue TL (1985). The anatomy of the neuropeptide $Y$ containing neurons in rat brain. Neuroscience, 15: 1159-1181.

29. Casto R \& Phillips MI (1986). Angiotensin II attenuates baroreflexes at nucleus tractus solitarius. American Journal of Physiology, 250: R193-R198.

30. Fuxe K, Agnati LF, Härfstrand A, Martire M, Goldstein M, Grimaldi R, Bernardi P, Zini I, Tatemoto K \& Mutt V (1984). Evidence for a modulation by neuropeptide $Y$ of the alpha-2 adrenergic transmission line in central adrenaline synapses. New possibilities for treatment of hypertensive disorders. Clinical and Experimental Hypertension, A6: 1951-1956.

31. Rettig R, Healy DP \& Printz MP (1986). Cardiovascular effects of microinjections of angiotensin II into the nucleus tractus solitarii. Brain Research, 364: 233-240.

32. De Jong W (1974). Noradrenaline: central inhibitory control of blood pressure and heart rate. European Journal of Pharmacology, 29: 179-181.

33. Carter DA, Vallejo $M$ \& Lightman NSL (1985). Cardiovascular effects of neuropeptide $Y$ in the nucleus tractus solitarius of rats: relationship with noradrenaline and vasopressin. Peptides, 6: 421 425.
34. Grundemar L, Wahlestedt C \& Reis DJ (1991). Neuropeptide $Y$ acts at an atypical receptor to evoke cardiovascular depression and to inhibit glutamate responsiveness in the brain stem. Journal of Pharmacology and Experimental Therapeutics, 258: 633-638.

35. Michelini LC \& Bonagamba LGH (1990). Angiotensin II as a modulator of baroreceptor reflexes in the brainstem of conscious rats. Hypertension, 15 (Suppl): I.451.50 .

36. Coveñas R, Fuxe K, Cintra A, Aguirre JA, Goldstein M \& Ganten D (1990). Evidence for the existence of angiotensin II like immunoreactivity in subpopulations of tyrosine hydroxylase immunoreactive neurons in the $\mathrm{A} 1$ and $\mathrm{C} 1$ area of the ventral medulla of the male rat. Neuroscience Letters, 114: 160-166.

37. Everitt BJ, Hökfelt $T$, Terenius L, Tatemoto K, Mutt V \& Goldstein M (1984). Differential coexistence of (NPY)-like immunoreactivity with catecholamines in the central nervous system of the rat. Neuroscience, 11: 443-462.

38. Fior DR, Yang S-N, Hedlund PB, Narvaez JA, Agnati LF \& Fuxe K (1994). Evidence for an antagonistic angiotensin $\mathrm{II} / \alpha_{2}$ adrenoceptor interaction in the nucleus tractus solitarii of the rat. European Journal of Pharmacology, 262: 271-282.

39. Young WSI \& Kuhar MJ (1980). Noradrenergic alpha-1 and alpha-2 receptors: light microscopic autoradiographic localization. Proceedings of the National Academy of Sciences, USA, 77: 1696-1700.

40. Yang S-N, Fior DR, Hedlund PB, Agnati LF \& Fuxe K (1994). Antagonistic regulation of $\alpha_{2}$-adrenoceptors by neuropeptide $Y$ receptor subtypes in the nucleus tractus solitarius. European Journal of Pharmacology, 271: 201-212.

41. Fior DR, Hedlund PB \& Fuxe K (1993) Autoradiographic evidence for a bradykinin/angiotensin II receptor-receptor interaction in the rat brain. Neuroscience Letters, 163: 58-62.

42. Mendelsohn FAO, Quirion R, Saavedra JM, Aguilera GE \& Catt KJ (1984). Autoradiographic localization of Ang II receptors in rat brain. Proceedings of the National Academy of Sciences, USA, 81: 15751579.

43. Fuxe K, Härfstrand A, Agnati LF, Kalia M, Fredholm B, Svensson T, Gustafsson JA, Lang R \& Ganten D (1987). Central catecholamine-neuropeptide $\mathrm{Y}$ interactions at the pre- and postsynaptic level in cardiovascular centers. Journal of Cardiovascular Pharmacology, 10: S1-S13. 
44. Agnati LF, Fuxe K, Benfenati F, Zini I \& Hökfelt T (1983). On the functional role of coexistence of 5-HT and substance $P$ in bulbospinal 5-HT neurons. Substance $P$ reduces affinity and increases density of ${ }^{3} \mathrm{H}-5-\mathrm{HT}$ binding sites. Acta Physiologica Scandinavica, 117: 299-301.

45. Agnati LF, Celani MF \& Fuxe K (1983). Cholecystokinin peptides in vitro modulate the characteristics of the striatal ${ }^{3} \mathrm{H}$ $\mathrm{N}$-propylnorapomorphine sites. Acta PhysiologicaScandinavica, 118: 79-81.

46. Li X-M, von Euler G, Hedlund PB, Finnman U-B \& Fuxe K (1993). The C-terminal neurotensin (8-13) fragment potently modulates rat neostriatal dopamine D2 receptors. European Journal of Pharmacology, 234: 125-128.

47. Kubo T \& Misu Y (1981). Pharmacological characterisation of the alpha-adrenoceptors responsible for a decrease of blood pressure in the nucleus tractus solitarii of the rat. Naunyn-Schmiedeberg's Archives of Pharmacology, 317: 120-125.

48. Zandberg $P$, De Jong $W$ \& De Wied $D$ (1979). Effects of catecholamine-receptor stimulating agents on blood pressure after local application in the nucleus tractus solitarii of the medulla oblongata. European Journal of Pharmacology, 55: 43-56.
49. Unnerstall JR, Kopajtic TA \& Kuhar MJ (1984). Distribution of $\alpha_{2}$ agonist binding sites in the rat and human central nervous system: analysis of some functional, anatomic correlates of the pharmacologic effects of clonidine and related adrenergic agents. Brain Research Review, 7: 69101.

50. Gehlert DR, Gackenheimer SL \& Schober DA (1991). Autoradiographic localization of subtypes of angiotensin II antagonist binding in rat brain. Neuroscience, 44: 501-514.

51. Yin DC, Chan JYH \& Chan SHH (1990). Interaction between angiotensin III and $\alpha_{2}$-adrenoceptors of the medulla oblongata involved in cardiovascular regulation in the rat. Regulatory Peptides, 29: 59-72.

52. Illes P \& Regenold JT (1990). Interaction between neuropeptide $Y$ and noradrenaline on central catecholamine neurons. Nature, 344: 62-63.

53. Tsuda K, Tsuda S, Matsuyama $Y$ \& Goldstein M (1990). Norepinephrine release and neuropeptide $Y$ in medulla oblongata of spontaneously hypertensive rats. Hypertension, 15: 784-790.

54. Fior DR, Yang S-N, Ganten U, Ganten D \& Fuxe K (1995). Evidence for a differential modulation of the alpha-2 adrenoceptors by angiotensin II in the nucleus tractus solitarii of the spontaneously hypertensive and the Wistar Kyoto normotensive rats. Brain Research, 679: 168-177.
55. Yang S-N, Fior DR, Hansson AC, Cintra A, Castellano M, Ganten U, Ganten D, Agnati LF \& Fuxe K (1997). Increased potency of neuropeptide $Y$ to antagonize $\alpha_{2}$-adrenoceptor function in the nucleus tractus solitarii of the spontaneously hypertensive rat. Neuroscience, 78: 803-813.

56. von Euler G, Fuxe K, Van der Ploeg I, Fredholm BB \& Agnati LF (1989). Pertussis toxin treatment counteracts intramembrane interactions between neuropeptide $\mathrm{Y}$ receptors and $\alpha_{2}$-adrenoceptors. European Journal of Pharmacology, 172: 435441.

57. Fuxe K, Härfstrand A, Agnati LF, von Euler G, Svensson T \& Fredholm B (1989). On the role of NPY in central cardiovascular regulation. In: Mutt V (Editor), Neuropeptide $Y$. Raven Press, New York.

58. Fior DR \& Fuxe K (1995). Bradykinin modulation of alpha-2 adrenoceptors in the nucleus tractus solitarii of the rat. An in vitro autoradiographical study. Neuropharmacology, 34: 81-88. 